\title{
Renal Pelvis and Ureter Cancer pN2 TNM
} Finding v8

National Cancer Institute

\section{Source}

National Cancer Institute. Renal Pelvis and Ureter Cancer pN2 TNM Finding v8. NCI

Thesaurus. Code C140352.

Renal pelvis and ureter cancer with metastasis in a single lymph node, more than $2 \mathrm{~cm}$ in greatest dimension; or multiple lymph nodes. (from AJCC 8th Ed.) 